\title{
Intraoperative Electron Beam Radiation Therapy (IOERT) Versus High-Dose-Rate Intraoperative Brachytherapy (HDR-IORT) in Patients With an R1 Resection for Locally Advanced or Locally Recurrent Rectal Cancer
}

Citation for published version (APA):

Voogt, E. L. K., van Rees, J. M., Hagemans, J. A. W., Rothbarth, J., Nieuwenhuijzen, G. A. P., Cnossen, J. S., Peulen, H. M. U., Dries, W. J. F., Nuyttens, J., Kolkman-Deurloo, I-K., Verhoef, C., Rutten, H. J. T., \& Burger, J. W. A. (2021). Intraoperative Electron Beam Radiation Therapy (IOERT) Versus High-DoseRate Intraoperative Brachytherapy (HDR-IORT) in Patients With an R1 Resection for Locally Advanced or Locally Recurrent Rectal Cancer. International Journal of Radiation Oncology Biology Physics, 110(4), 1032-1043. https://doi.org/10.1016/j.ijrobp.2021.02.006

Document status and date:

Published: 15/07/2021

DOI:

10.1016/j.jijrobp.2021.02.006

Document Version:

Publisher's PDF, also known as Version of record

\section{Document license:}

Taverne

Please check the document version of this publication:

- A submitted manuscript is the version of the article upon submission and before peer-review. There can be important differences between the submitted version and the official published version of record. People interested in the research are advised to contact the author for the final version of the publication, or visit the DOI to the publisher's website.

- The final author version and the galley proof are versions of the publication after peer review.

- The final published version features the final layout of the paper including the volume, issue and page numbers.

Link to publication

\footnotetext{
General rights rights.

- You may freely distribute the URL identifying the publication in the public portal. please follow below link for the End User Agreement:

www.umlib.nl/taverne-license

Take down policy

If you believe that this document breaches copyright please contact us at:

repository@maastrichtuniversity.nl

providing details and we will investigate your claim.
}

Copyright and moral rights for the publications made accessible in the public portal are retained by the authors and/or other copyright owners and it is a condition of accessing publications that users recognise and abide by the legal requirements associated with these

- Users may download and print one copy of any publication from the public portal for the purpose of private study or research.

- You may not further distribute the material or use it for any profit-making activity or commercial gain

If the publication is distributed under the terms of Article $25 \mathrm{fa}$ of the Dutch Copyright Act, indicated by the "Taverne" license above,

Download date: 26 Apr. 2023 


\title{
Intraoperative Electron Beam Radiation Therapy (IOERT) Versus High-Dose-Rate Intraoperative Brachytherapy (HDR-IORT) in Patients With an R1 Resection for Locally Advanced or Locally Recurrent Rectal Cancer
}

\author{
Eva L.K. Voogt, MD, ${ }^{*}$ Jan M. van Rees, MD, ${ }^{\dagger}$ Jan A.W. Hagemans, MD, \\ PhD, ${ }^{\dagger}$ Joost Rothbarth, MD, PhD, ${ }^{\dagger}$ Grad A.P. Nieuwenhuijzen, MD, \\ PhD, ${ }^{*}$ Jeltsje S. Cnossen, MD, PhD, Heike M.U. Peulen, MD, PhD, \\ Wim J.F. Dries, PhD, Joost Nuyttens, MD, PhD, \\ Inger-Karine Kolkman-Deurloo, $\mathrm{PhD},{ }^{\S}$ Cornelis Verhoef, MD, PhD, \\ Harm J.T. Rutten, MD, PhD, ${ }^{*} \|$ and Jacobus W.A. Burger, MD, PhD*, \\ ${ }^{*}$ Department of Surgery, Catharina Hospital Eindhoven, Eindhoven, The Netherlands; ${ }^{\dagger}$ Department \\ of Surgical Oncology, Erasmus MC Cancer Institute, Rotterdam, The Netherlands; ${ }^{\ddagger}$ Department of \\ Radiation Oncology, Catharina Hospital Eindhoven, Eindhoven, The Netherlands; ${ }^{\S}$ Department of \\ Radiation Oncology, Erasmus MC Cancer Institute, Rotterdam, The Netherlands; and "GROW School \\ for Oncology and Developmental Biology, Maastricht University, Maastricht, The Netherlands
}

Received Aug 6, 2020. Accepted for publication Feb 2, 2021.

\footnotetext{
Purpose: Intraoperative radiation therapy (IORT), delivered by intraoperative electron beam radiation therapy (IOERT) or high-dose-rate intraoperative brachytherapy (HDR-IORT), may reduce the local recurrence rate in patients with locally advanced and locally recurrent rectal cancer (LARC and LRRC, respectively). The aim of this study was to compare the oncological outcomes between both IORT modalities in patients with LARC or LRRC who underwent a microscopic irradical (R1) resection.

Methods: All consecutive patients who received IORT because of an R1 resection of LARC or LRRC between 2000 and 2016 in two tertiary referral centers were included. In LARC, a resection margin of $\leq 2$ mm was considered $\mathrm{R} 1$. A resection margin of $0 \mathrm{~mm}$ was considered R1 in LRRC.

Results: In total, 215 patients with LARC were included, of whom 151 (70\%) received IOERT and 64 (30\%) received HDRIORT; in addition, 158 patients with LRRC were included, of whom 112 (71\%) received IOERT and 46 (29\%) received HDRIORT. After multivariable analyses, the overall survival was not significantly different between the two IORT modalities. The local recurrence-free survival was significantly longer in patients treated with HDR-IORT, both in LARC (hazard ratio [HR], 0.496; 95\% CI, 0.253-0.973; $P=.041)$ and LRRC (HR, 0.567; 95\% CI, 0.349-0.920; $P=.021)$. In patients with LARC,

Corresponding author: Eva L. K. Voogt, MD, PhD; E-mail: eva. voogt@catharinaziekenhuis.nl

Disclosures: none.

Research data are stored in an institutional repository and will be shared upon request to the corresponding author.

Supplementary material for this article can be found at https://doi.org/ 10.1016/j.ijrobp.2021.02.006.
}

Int J Radiation Oncol Biol Phys, Vol. 110, No. 4, pp. 1032-1043, 2021 0360-3016/\$ - see front matter (C) 2021 Elsevier Inc. All rights reserved. https://doi.org/10.1016/j.ijrobp.2021.02.006 
major postoperative complications were similar for both IORT modalities (IOERT, 30\%; HDR-IORT, 27\%), whereas in patients with LRRC, the incidence of major postoperative complications was higher after HDR-IORT (IOERT, 26\%; HDRIORT, $46 \%)$.

Conclusions: This study showed a significantly better local recurrence-free survival in favor of HDR-IORT in patients with an R1 resection for LARC or LRRC. Optimization of the IOERT technique seems warranted. (C) 2021 Elsevier Inc. All rights reserved.

\section{Introduction}

Achievement of a resection with clear margins (R0 resection) is the most important goal in the treatment of locally advanced and locally recurrent rectal cancer (LARC and LRRC, respectively), as it offers the best prognosis in terms of recurrence-free and overall survival. Patients at risk for a resection without clear margins (R1 resection) are offered neoadjuvant treatment, consisting of external beam radiation therapy (EBRT) with a dose of 45 Gy to 50 Gy with concomitant chemotherapy, as this has been shown to be effective in local downstaging of the tumor and to increase the likelihood of achieving an R0 resection, thereby reducing the risk of local relapse. ${ }^{1,2}$ In addition, in patients at risk for an R1 resection, multivisceral resections are usually necessary, requiring extensive expertise and thus centralization of care. Nevertheless, an R1 resection occurs in approximately $10 \%$ to $20 \%$ of patients with LARC and $40 \%$ of those with LRRC. ${ }^{3-5}$ Preoperative radiation therapy with a dose of 45 Gy to 50 Gy cannot compensate for an R1 resection. ${ }^{6} \mathrm{~A}$ dose in excess of $60 \mathrm{~Gy}$ may be able to eradicate microscopic residual disease; however, administration of radiation therapy at a dose higher than $50 \mathrm{~Gy}$ is associated with excessive toxicity, because this level of exposure exceeds the normal-tissue tolerance, which prohibits increasing the EBRT dosage. ${ }^{7-9}$

Intraoperative radiation therapy (IORT), the delivery of a single boost of radiation therapy during surgery, has the ability to deliver a higher dose to the areas at highest risk for tumor involvement while at the same time allowing dose-limiting structures and organs such as the ureters and small intestine to be positioned outside the radiation field, thus mitigating the problem of increased toxicity resulting from the application of a higher dosage of radiation therapy. The biological equivalent of one single fraction IORT equals 1.5 to 2.5 times the dose delivered by conventional fractionation. ${ }^{8}$ Prior studies have suggested that use of IORT in patients with a positive microscopically circumferential resection margin reduces local recurrence rates. ${ }^{10-12}$

IORT can be delivered through different modalities, including intraoperative electron beam radiation therapy (IOERT) and high-dose-rate intraoperative brachytherapy (HDR-IORT), the former being the most frequently used based on the literature. ${ }^{12,13}$ The advantages of IOERT in relation to HDR-IORT include shorter set-up and treatment times and a more homogeneous radiation dose to be delivered throughout the tissue depth. An important limitation of IOERT, however, is that the applicators are poorly suited to curved areas or narrow spaces. In contrast, HDRIORT is a more time-consuming procedure, but the use of flexible applicators allows for application to any curved surface. In addition, with HDR-IORT, it is possible to irradiate a larger area, and the steeper dose gradient between the target surface and the reference depth leads to a more concentrated dose to be delivered at the surface of the target area. ${ }^{14}$

This study aimed to compare the long-term oncological outcomes between patients who received either IOERT or HDR-IORT after an R1 resection for LARC or LRRC.

\section{Patients and Methods}

\section{Patients}

All consecutive patients with LARC or LRRC who underwent a resection between 2000 and 2016 in the Catharina Hospital Eindhoven (CZE) or Erasmus MC Cancer Institute (EMC) were identified from a prospectively maintained database. We included all patients with an R1 resection after undergoing intentionally curative surgery in whom IORT was delivered by either IOERT or HDRIORT. For the purpose of this study, in patients with LARC, an R1 resection was defined as a resection with involved or close margins $(\leq 2 \mathrm{~mm})$, as this margin was the cutoff value to deliver IORT based on a study by Nagtegaal et al. ${ }^{15}$ In patients with LRRC, an R1 resection was defined as a resection with involved margins, in accordance with the literature. ${ }^{16}$ Patients with peritoneal metastases, as well as patients who did not receive neoadjuvant radiation therapy, were excluded. The potential indication for IORT was determined during a meeting of a multidisciplinary tumor board, which included experienced surgeons, medical oncologists, radiation oncologists, and radiologists. The study was approved by both institutional local medical ethics committees (Medical research Ethics Committees United Nieuwegein, registration number W19.031 and Medical Ethics Review Committee Erasmus MC, registration number MEC-2017-449). Follow-up was completed until January 1, 2020. 


\section{Neoadjuvant treatment and surgical procedures}

All patients received neoadjuvant radiation therapy, which was delivered in one of the two tertiary referral centers or in a referring hospital. In patients with LARC, neoadjuvant radiation therapy consisted of either short-course (25 Gy in 5 fractions of $5 \mathrm{~Gy}$ ) or long-course (45-50.4 Gy in fractions of 1.8-2 Gy) EBRT. In patients with LRRC, neoadjuvant radiation therapy consisted of either long-course EBRT (45-50.4 Gy in fractions of 1.8-2 Gy) or reirradiation (30 Gy in fractions of $2 \mathrm{~Gy}$ ). In case of long-course radiation therapy or reirradiation, concomitant capecitabine was administered $\left(825 \mathrm{mg} / \mathrm{m}^{2}\right.$ twice daily on radiation therapy days). Induction chemotherapy, generally CAPOX (capecitabine, oxaliplatin) or FOLFOX (leucovorin, 5fluorouracil, oxaliplatin), was administered to a minority of patients before or after radiation therapy treatment. This was usually to treat and observe the biological behavior of synchronous metastases; induction chemotherapy was not considered the standard of care during the study period. After patients finished the neoadjuvant treatment course, pelvic magnetic resonance imaging was performed to assess the resectability.

The extent of pelvic surgery depended on the location of the tumor and the involvement of adjacent structures and was performed by experienced surgical oncologists. For specific reconstructive procedures, other specialists such as urologists or plastic surgeons were involved.

\section{Intraoperative radiation therapy}

At both referral centers, IORT was delivered in cases with clinically suspected narrow or involved margins or in cases with narrow or microscopically involved margins, based on assessment of frozen sections.

At the CZE, all patients who underwent surgery for LARC or LRRC were scheduled in an operating room with IORT facilities. The IORT was delivered by IOERT. In earlier years of the study, this was delivered using an Elekta SL-25 linear accelerator (Elekta Oncology Systems, Stockholm, Sweden). ${ }^{17}$ From 2016 onward, IORT was delivered using a Mobetron 2000 linear accelerator (IntraOp Inc, Sunnyvale, California). Generally, the IORT dose was $10 \mathrm{~Gy}$ or $12.5 \mathrm{~Gy}$. The dose was prescribed to the $90 \%$ isodose surface, generally ranging from $12 \mathrm{~mm}$ to 18 $\mathrm{mm}$ in depth, with energies ranging from $6 \mathrm{MeV}$ to $8 \mathrm{MeV}$ using a $30^{\circ}$ to $45^{\circ}$ beveled applicator of $5 \mathrm{~cm}$ to $7 \mathrm{~cm}$ in length. The rationale for the dosing strategy depended on the target area, the normal tissue at risk, and the anatomy of the patient.

At the EMC, all patients who underwent surgery for LARC or LRRC and in whom a resection margin of $\leq 2$ $\mathrm{mm}$ was expected were planned in an operating room with IORT facilities. The IORT was delivered by high-dose-rate brachytherapy using a flexible intraoperative temple (i.e. the FIT procedure), which has been described previously. ${ }^{18}$
In short, HDR-IORT was delivered using a flexible 5-mmthick pad made of flexible silicon, with a dose of $10 \mathrm{~Gy}$ prescribed at a depth of $1 \mathrm{~cm}$ from the applicator surface. The size and shape were adjusted according to the surface of the area at risk.

\section{Follow-up}

Follow-up was performed according to the Dutch guidelines for colorectal cancer; carcinoembryonic antigen (CEA) measurements were performed 4 times a year during the first 2 years and twice a year during years 3 to 5 . Ultrasonography of the liver was performed twice a year during the first 2 years and once a year thereafter. In case of an elevated CEA concentration or new ultrasonography findings, a thoracoabdominal computed tomography (CT) scan or a fluorodeoxyglucose (FDG) positron emission tomography (PET) / CT scan was performed. At the EMC, ultrasonography was replaced by thoracoabdominal CT scan for the majority of patients with LRRC from 2011 onward.

\section{Study endpoints and statistics}

Endpoints were overall survival (OS), local recurrence-free survival (LRFS), and the incidence of major postoperative complications. Overall survival was calculated from the date of surgery until the date of death from any cause, or was censored at the last follow-up. Local recurrence-free survival was calculated from the date of surgery until the date local recurrence was detected by imaging or histology, or was censored at the last follow-up or death. Postoperative complications were graded according to the Clavien-Dindo classification. ${ }^{19}$ Major complications were defined as a complication of grade 3 or greater.

Continuous data were reported as medians and interquartile ranges (IQRs) and categorical data as counts and percentages. Group comparisons were performed using Mann-Whitney U, $\chi^{2}$, or Fisher exact tests, as appropriate. Survival analyses were performed using the Kaplan-Meier method, and data were compared using log-rank tests. Two-sided $P$ values $<.05$ were considered statistically significant. Cox proportional hazards modeling was performed for multivariable analysis using the stepwise backward selection option. In addition to the type of IORT, variables identified with a $P$ value $<.50$ in the univariable analysis were included in the multivariable analysis. Statistical analyses were performed using IBM SPSS Statistics, version 25.0 (IBM Corp, Armonk, New York).

\section{Results}

\section{Locally advanced rectal cancer}

In total, 1865 patients underwent a resection for LARC in one of the two tertiary referral centers between 2000 and 
Table 1 Patient, tumor, and surgical characteristics in patients with locally advanced rectal cancer*

\begin{tabular}{|c|c|c|c|c|}
\hline Characteristic & $\begin{array}{c}\text { Total, No. }(\%) \\
(\mathrm{N}=215)\end{array}$ & $\begin{array}{l}\text { IOERT, No. }(\%) \\
(\mathrm{n}=151)\end{array}$ & $\begin{array}{l}\text { HDR-IORT, No. }(\%) \\
(\mathrm{n}=64)\end{array}$ & $P$ value \\
\hline \multicolumn{5}{|l|}{ Gender } \\
\hline Male & $151(70)$ & $105(70)$ & $46(72)$ & .732 \\
\hline \multicolumn{5}{|l|}{ Age at resection, $\mathrm{y}$} \\
\hline$<70$ & $156(73)$ & $105(70)$ & $51(80)$ & .127 \\
\hline cT3 & $57(27)$ & $35(23)$ & $22(34)$ & \multirow[t]{2}{*}{.094} \\
\hline cT4 & $157(73)$ & $115(77)$ & $42(66)$ & \\
\hline \multicolumn{5}{|l|}{ Synchronous metastases } \\
\hline No & $180(84)$ & $129(85)$ & $51(80)$ & \multirow[t]{2}{*}{.297} \\
\hline Yes & $35(16)$ & $22(15)$ & $13(20)$ & \\
\hline 5x5 Radiation therapy & $20(9)$ & $14(9)$ & $6(9)$ & \multirow[t]{2}{*}{.981} \\
\hline (Chemo)radiation therapy & $195(91)$ & $137(91)$ & $58(91)$ & \\
\hline \multicolumn{5}{|l|}{$\begin{array}{l}\text { Interval radiation } \\
\text { therapy-surgery, wk }\end{array}$} \\
\hline$<8$ & $31(15)$ & $21(14)$ & $10(16)$ & \multirow[t]{3}{*}{.137} \\
\hline $8-12$ & $98(46)$ & $63(42)$ & $35(55)$ & \\
\hline$>12$ & $85(40)$ & $66(44)$ & $19(30)$ & \\
\hline \multicolumn{5}{|l|}{ Surgical procedure } \\
\hline LAR & $46(21)$ & $36(24)$ & $10(16)$ & \multirow[t]{2}{*}{.362} \\
\hline APR & 37 (17) & $24(16)$ & $13(20)$ & \\
\hline Yes & $25(12)$ & $21(14)$ & $4(6)$ & .106 \\
\hline \multicolumn{5}{|l|}{ Pathologic tumor stage } \\
\hline $\mathrm{pT} 1 / 2$ & $4(2)$ & $2(1)$ & $2(3)$ & \multirow[t]{3}{*}{.104} \\
\hline pT3 & $128(60)$ & $96(64)$ & $32(50)$ & \\
\hline pT4 & $82(38)$ & $52(35)$ & $30(47)$ & \\
\hline Pathologic nodal stage & & & & \\
\hline $\mathrm{pN} 0$ & $107(50)$ & 74 (49) & $33(52)$ & .918 \\
\hline $\mathrm{pN} 1$ & $70(33)$ & $50(33)$ & $20(32)$ & \\
\hline $\mathrm{pN} 2$ & $36(17)$ & $26(17)$ & $10(16)$ & \\
\hline Resection margin, $\mathrm{mm}$ & & & & \\
\hline 0 & $93(43)$ & $64(42)$ & $29(45)$ & .844 \\
\hline$>0$ to $\leq 1$ & $73(34)$ & $51(34)$ & $22(34)$ & \\
\hline$>1$ to $\leq 2$ & $49(23)$ & $36(24)$ & $13(20)$ & \\
\hline Complications & & & & \\
\hline Clavien-Dindo 0-II & $140(71)$ & $93(71)$ & $47(73)$ & .665 \\
\hline Clavien-Dindo III-V & $56(29)$ & $39(30)$ & $17(27)$ & \\
\hline
\end{tabular}




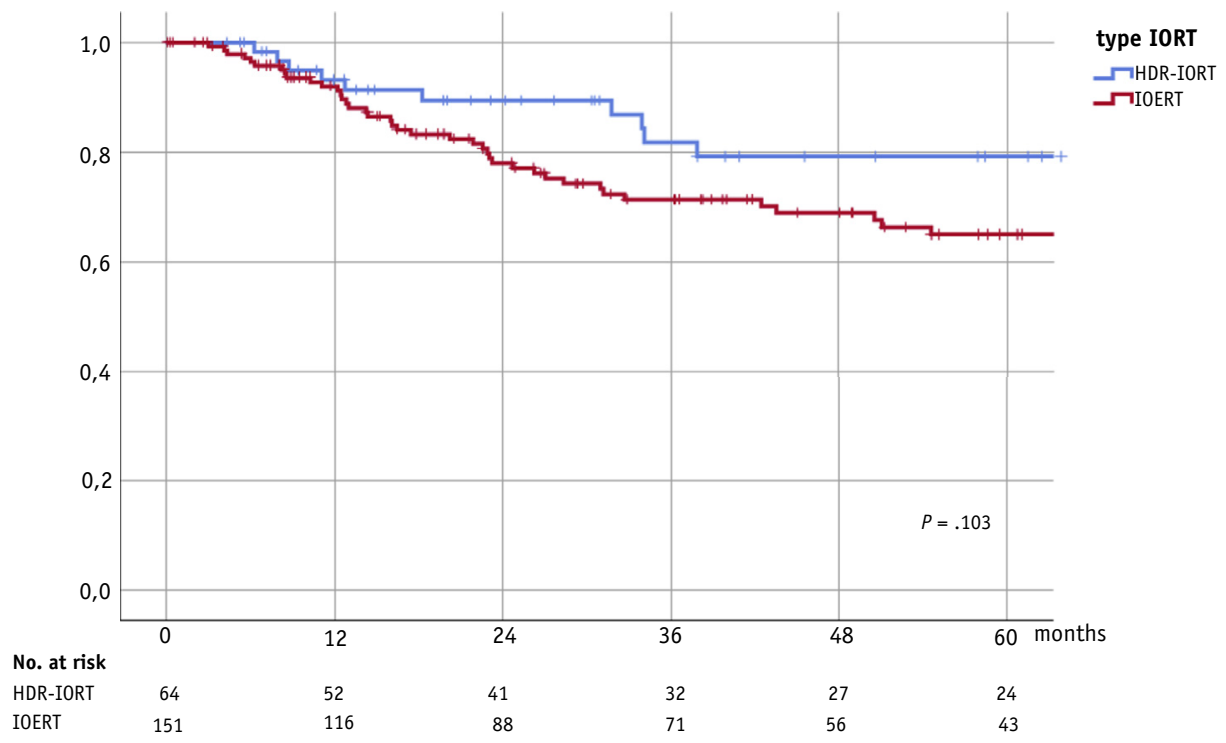

Fig. 1. Kaplan-Meier curve for local recurrence-free survival in patients with locally advanced rectal cancer.

2016. An R1 resection was noted in 347 of 1865 patients, of whom 218 received IORT. Three patients were excluded from further analysis because of peritoneal metastases (2 patients) or for having received no neoadjuvant radiation therapy (1 patient). In 151 of the 215 included patients (70\%), IORT was delivered by IOERT, whereas 64 patients (30\%) received HDR-IORT. Patient, tumor, and treatment characteristics are summarized in Table 1 . Most patients (73\%) were diagnosed with a T4 tumor, and neoadjuvant treatment generally consisted of long-course radiation therapy (91\% of patients). Only a minority of patients (16\%) were diagnosed with synchronous metastases. Most patients $(61 \%)$ underwent a multivisceral resection. The procedure time was significantly longer in patients who received HDR-IORT compared with IOERT $(P<.001)$.

The HDR-IORT was delivered with a prescribed dose of $10 \mathrm{~Gy}$ in all patients, effectively leading to an average dose of \pm 17 Gy at the target surface. The median treated area was not known. The IOERT was delivered at a dose of $10 \mathrm{~Gy}$ at the $90 \%$ isodose surface in 130 patients (86\%), a dose of 12.5 Gy in 20 patients (13\%), and a dose of 15 Gy in 1 patient (1\%). The median prescription depth (D90) was $14 \mathrm{~mm}$ (IQR, 12-15 mm), with a median treated area of $28 \mathrm{~cm}^{2}$ (IQR, 27-32 $\mathrm{cm}^{2}$ ).

\section{Locally advanced rectal cancer-survival outcomes}

The median OS was 48 months (IQR, 19-111 months) for patients treated with HDR-IORT and 41 months (IQR, 21137 months) for patients treated with IOERT. For patients who received HDR-IORT, the 3-year and 5-year OS rates were $61 \%$ and $47 \%$, respectively. This was not significantly different compared with patients who received IOERT (3year and 5-year OS rates, 58\% and 40\%, respectively; $P=$
989). Median LRFS was not reached. The 3-year and 5year LRFS rates for patients who received HDR-IORT were $82 \%$ and $79 \%$, respectively. For patients who received IOERT, these rates were $71 \%$ and $65 \%$, respectively $(P=.103$; Fig. 1$)$.

Results of the univariable and multivariable analyses are shown in Table 2. After multivariable analysis, the IORT modality had no significant association with OS, whereas age, time between radiation therapy and surgery, pathologic tumor and lymph node stage (pT and $\mathrm{pN}$, respectively), and resection margin did. For LRFS, multivariable analysis showed a significantly favorable LRFS in patients treated with HDR-IORT compared with those treated with IOERT (HR, 0.504; 95\% CI, 0.254-0.999; $P=.050$ ). In addition, the time between radiation therapy and surgery, $\mathrm{pT}$ stage, and resection margin were significantly related to the development of a local recurrence.

\section{Locally recurrent rectal cancer}

In total, 587 patients underwent a resection for LRRC in one of the two tertiary referral centers between 2000 and 2016. Of these 587 patients, 196 had an R1 resection, of whom 161 received IORT. Three patients were excluded from further analysis; 1 patient had peritoneal metastases, and 2 patients did not receive neoadjuvant radiation therapy. Of the 158 patients receiving IORT, 112 (71\%) received IOERT and 46 (29\%) received HDR-IORT. Patient, tumor, and treatment characteristics are shown in Table 3. Patients who received HDR-IORT received neoadjuvant (chemo)radiation therapy instead of (chemo)reirradiation more often than patients who received IOERT $(P$ $=.001)$. The interval between the end of neoadjuvant radiation therapy and surgery was significantly shorter in 
Table 2 Univariable and multivariable analysis for overall and local recurrence-free survival in patients with locally advanced rectal cancer*

\begin{tabular}{|c|c|c|c|c|c|c|c|c|c|c|c|c|}
\hline \multirow[b]{2}{*}{ Variable } & \multicolumn{6}{|c|}{ Overall survival } & \multicolumn{6}{|c|}{ Local recurrence-free survival } \\
\hline & HR & $95 \% \mathrm{CI}$ & $\begin{array}{c}P \\
\text { value }\end{array}$ & HR & $95 \% \mathrm{CI}$ & $P$ value & HR & $95 \% \mathrm{CI}$ & $\begin{array}{c}P \\
\text { value }\end{array}$ & HR & $95 \% \mathrm{CI}$ & $\begin{array}{c}P \\
\text { value }\end{array}$ \\
\hline \multicolumn{13}{|l|}{ Type of IORT } \\
\hline IOERT & 1.00 & $1[\operatorname{Ref}]$ & & 1.00 & $1[\operatorname{Ref}]$ & & 1.00 & $1[$ Ref $]$ & & 1.00 & $1[\mathrm{Ref}]$ & \\
\hline HDR-IORT & 1.002 & $\begin{array}{l}0.712- \\
1.411\end{array}$ & .989 & 1.096 & $\begin{array}{l}0.757- \\
1.586\end{array}$ & .627 & 0.579 & $\begin{array}{l}0.297- \\
1.126\end{array}$ & .108 & 0.504 & $\begin{array}{l}0.254- \\
0.999\end{array}$ & .050 \\
\hline \multicolumn{13}{|l|}{ Age, y } \\
\hline$<70$ & 1.00 & $1[\operatorname{Ref}]$ & & 1.00 & $1[\operatorname{Ref}]$ & & 1.00 & $1[$ Ref $]$ & & & & \\
\hline$\geq 70$ & 1.443 & $\begin{array}{l}1.026- \\
2.031\end{array}$ & .035 & 2.131 & $\begin{array}{l}1.478- \\
3.073\end{array}$ & $<.001$ & 0.585 & $\begin{array}{l}0.285- \\
1.201\end{array}$ & .144 & & & \\
\hline \multicolumn{13}{|l|}{ Gender } \\
\hline Male & 1.00 & $1[\operatorname{Ref}]$ & & & & & 1.00 & $1[\operatorname{Ref}]$ & & & & \\
\hline Female & 1.251 & $\begin{array}{l}0.894- \\
1.752\end{array}$ & .192 & & & & 1.486 & $\begin{array}{l}0.838- \\
2.636\end{array}$ & .175 & & & \\
\hline \multicolumn{13}{|l|}{ Clinical tumor stage } \\
\hline $\mathrm{T} 3$ & 1.00 & $1[\operatorname{Ref}]$ & & & & & 1.00 & $1[\operatorname{Ref}]$ & & & & \\
\hline $\mathrm{T} 4$ & 1.082 & $\begin{array}{l}0.755- \\
1.550\end{array}$ & .669 & & & & 1.273 & $\begin{array}{l}0.667- \\
2.432\end{array}$ & .465 & & & \\
\hline \multicolumn{13}{|l|}{ Synchronous metastases } \\
\hline No & 1.00 & $1[\operatorname{Ref}]$ & & & & & 1.00 & $1[\operatorname{Ref}]$ & & & & \\
\hline Yes & 1.267 & $\begin{array}{l}0.829- \\
1.937\end{array}$ & .275 & & & & 1.358 & $\begin{array}{l}0.680- \\
2.714\end{array}$ & .386 & & & \\
\hline \multicolumn{13}{|l|}{ Neoadjuvant chemotherapy } \\
\hline No & 1.00 & $1[\operatorname{Ref}]$ & & & & & 1.00 & $1[\operatorname{Ref}]$ & & & & \\
\hline Yes & 1.352 & $\begin{array}{l}0.778- \\
2.347\end{array}$ & .284 & & & & 2.241 & $\begin{array}{l}1.007- \\
4.984\end{array}$ & .048 & & & \\
\hline \multicolumn{13}{|l|}{ Neoadjuvant radiation therapy } \\
\hline $5 \times 5$ Radiation therapy & 1.00 & $1[\operatorname{Ref}]$ & & & & & 1.00 & $1[\operatorname{Ref}]$ & & & & \\
\hline (Chemo)radiation therapy & 0.666 & $\begin{array}{l}0.390- \\
1.135\end{array}$ & .135 & & & & 0.538 & $\begin{array}{l}0.229- \\
1.265\end{array}$ & .155 & & & \\
\hline \multicolumn{13}{|c|}{$\begin{array}{l}\text { Time between RT and surgery, } \\
\text { wk }\end{array}$} \\
\hline$<8$ & 1.00 & $1[\operatorname{Ref}]$ & & 1.00 & $1[\operatorname{Ref}]$ & & 1.00 & $1[\operatorname{Ref}]$ & & 1.00 & Ref & \\
\hline $8-12$ & 1.056 & $\begin{array}{l}0.662- \\
1.685\end{array}$ & .818 & 0.952 & $\begin{array}{l}0.592- \\
1.530\end{array}$ & .838 & 1.985 & $\begin{array}{l}0.688- \\
5.721\end{array}$ & .204 & 2.187 & $\begin{array}{l}0.749- \\
6.383\end{array}$ & .152 \\
\hline$>12$ & 1.572 & $\begin{array}{l}0.971- \\
2.545\end{array}$ & .066 & 1.721 & $\begin{array}{l}1.049- \\
2.822\end{array}$ & .032 & 2.901 & $\begin{array}{l}1.001- \\
8.408\end{array}$ & .050 & 3.168 & $\begin{array}{l}1.075- \\
9.339\end{array}$ & .037 \\
\hline \multicolumn{13}{|l|}{ Type of surgery } \\
\hline LAR & 1.00 & $1[\operatorname{Ref}]$ & & & & & 1.00 & $1[\operatorname{Ref}]$ & & & & \\
\hline APR & 0.781 & $\begin{array}{l}0.475- \\
1.285\end{array}$ & .330 & & & & 0.683 & $\begin{array}{l}0.243- \\
1.920\end{array}$ & .469 & & & \\
\hline Multivisceral resection & 0.766 & $\begin{array}{l}0.519- \\
1.132\end{array}$ & .181 & & & & 1.295 & $\begin{array}{l}0.624- \\
2.686\end{array}$ & .487 & & & \\
\hline \multicolumn{13}{|l|}{ Adjuvant therapy } \\
\hline No & 1.00 & $1[\operatorname{Ref}]$ & & & & & 1.00 & $1[\operatorname{Ref}]$ & & & & \\
\hline Yes & 1.012 & $\begin{array}{l}0.619- \\
1.655\end{array}$ & .962 & & & & 1.518 & $\begin{array}{l}0.713- \\
3.232\end{array}$ & .279 & & & \\
\hline \multicolumn{13}{|l|}{ Pathologic tumor stage } \\
\hline $\mathrm{T} 1-3$ & 1.00 & $1[\operatorname{Ref}]$ & & 1.00 & $1[\operatorname{Ref}]$ & & 1.00 & $1[\operatorname{Ref}]$ & & 1.00 & Ref & \\
\hline $\mathrm{T} 4$ & 2.082 & $\begin{array}{l}1.513- \\
2.865\end{array}$ & $<.001$ & 1.890 & $\begin{array}{l}1.345- \\
2.656\end{array}$ & $<.001$ & 2.768 & $\begin{array}{l}1.591- \\
4.816\end{array}$ & $<.001$ & 2.386 & $\begin{array}{l}1.308- \\
4.350\end{array}$ & .005 \\
\hline \multicolumn{13}{|l|}{ Pathologic lymph node stage } \\
\hline No & 1.00 & $1[\operatorname{Ref}]$ & & 1.00 & $1[\operatorname{Ref}]$ & & 1.00 & $1[\operatorname{Ref}]$ & & & & \\
\hline N1 & 1.215 & $\begin{array}{l}0.850- \\
1.738\end{array}$ & .285 & 1.385 & $\begin{array}{l}0.955- \\
2.008\end{array}$ & .086 & 1.134 & $\begin{array}{l}0.612- \\
2.101\end{array}$ & .690 & & & \\
\hline
\end{tabular}


Table 2 (continued)

\begin{tabular}{|c|c|c|c|c|c|c|c|c|c|c|c|c|}
\hline \multirow[b]{2}{*}{ Variable } & \multicolumn{6}{|c|}{ Overall survival } & \multicolumn{6}{|c|}{ Local recurrence-free survival } \\
\hline & HR & $95 \% \mathrm{CI}$ & $\begin{array}{c}P \\
\text { value }\end{array}$ & HR & $95 \% \mathrm{CI}$ & $P$ value & HR & $95 \% \mathrm{CI}$ & $\begin{array}{c}P \\
\text { value }\end{array}$ & HR & $95 \% \mathrm{CI}$ & $\begin{array}{c}P \\
\text { value }\end{array}$ \\
\hline \multicolumn{13}{|l|}{ Resection margin, mm } \\
\hline 0 & 1.00 & $1[\operatorname{Ref}]$ & & 1.00 & $1[\operatorname{Ref}]$ & & 1.00 & $1[\operatorname{Ref}]$ & & 1.00 & Ref & \\
\hline$>1$ to $\leq 2$ & 0.488 & $\begin{array}{l}0.315- \\
0.756\end{array}$ & .001 & 0.402 & $\begin{array}{l}0.248- \\
0.652\end{array}$ & $<.001$ & 0.286 & $\begin{array}{l}0.119- \\
0.688\end{array}$ & .005 & 0.324 & $\begin{array}{l}0.129- \\
0.811\end{array}$ & .016 \\
\hline \multicolumn{13}{|l|}{ Complications } \\
\hline Clavien-Dindo 0-II & 1.00 & $1[\operatorname{Ref}]$ & & & & & 1.00 & $1[\operatorname{Ref}]$ & & & & \\
\hline Clavien-Dindo III-V & 0.996 & $\begin{array}{l}0.689- \\
1.439\end{array}$ & .982 & & & & 0.984 & $\begin{array}{l}0.511- \\
1.929\end{array}$ & .984 & & & \\
\hline
\end{tabular}

patients who received HDR-IORT than in patients who received IOERT $(P=.001)$, but the procedure time was significantly longer $(P<.001)$.

The HDR-IORT was delivered at a dose of $10 \mathrm{~Gy}$ in all patients, effectively leading to an average dose of \pm 17 Gy at the target surface. The median treated area was not known. The IOERT was delivered at a dose of $10 \mathrm{~Gy}$ at the $90 \%$ isodose surface in a majority of patients $(67,60 \%)$, and in 45 patients (40\%) 12.5 Gy was delivered. The median prescription depth (D90) was $14 \mathrm{~mm}$ (IQR, 12-20 mm), with a median treated area of $32 \mathrm{~cm}^{2}$ (IQR, 27-39 $\left.\mathrm{cm}^{2}\right)$.

\section{Locally recurrent rectal cancer-survival outcomes}

The median OS was 28 months (IQR, 17-43 months) for patients treated with HDR-IORT and 31 months (IQR, 1252 months) for patients treated with IOERT. The 3-year and 5 -year OS rates were $39 \%$ and $12 \%$, respectively, for patients who received HDR-IORT, which was not significantly different compared with patients who received IOERT (3-year and 5-year OS rates of $44 \%$ and 18\%, respectively; $P=.747$ ). The median LRFS was 19 months (IQR, 12-27 months) for patients treated with HDR-IORT and 14 months (IQR, 12-16 months) for patients treated with IOERT. The 3-year and 5-year LRFS rates for patients who received HDR-IORT were $38 \%$ and $34 \%$, respectively. For patients who received IOERT, these rates were $29 \%$ and $19 \%$, respectively $(P=.139$; Fig 2$)$.

Table 4 shows the results of the univariable and multivariable analyses. As neoadjuvant radiation therapy for the primary tumor and the recurrent tumor were strongly correlated, only neoadjuvant radiation therapy for the primary tumor was included in the multivariable analysis. After multivariable analysis, the IORT modality had no significant association with OS, whereas age and $\mathrm{N}$-stage of the primary tumor did. For LRFS, multivariable analysis revealed a significantly favorable LRFS in patients treated with HDR-IORT compared with patients treated with IOERT (HR, 0.567; 95\% CI, 0.349-0.920; $P=.021$ ). In addition, the pT stage and $\mathrm{pN}$ stage of the primary tumor were significantly related to the development of a local recurrence.

\section{Complications}

Of the 215 patients with LARC, data on postoperative complications were available in 196 cases (91\%). Major complications were comparable between the two groups, as $30 \%$ of patients treated with IOERT and $27 \%$ of patients treated with HDR-IORT had at least 1 complication with a Clavien-Dindo grade $\geq 3(P=.665)$. In patients who experienced a major complication, the most common were presacral abscess (27\%), bleeding (11\%), abdominal wound dehiscence with evisceration (11\%), intraabdominal abscess $(9 \%)$, perineal wound necrosis $(5 \%)$, leakage of the ureter or bladder reconstruction (5\%), anastomotic leakage $(5 \%)$, and ureter stenosis (5\%) (Table E1). In-hospital mortality was observed in 2 of 151 patients $(1 \%)$ in the IOERT group, whereas no in-hospital mortality was observed in the HDR-IORT group $(P=.546)$.

Of the 158 patients with LRRC, data on postoperative complications were available in 157 cases (99\%). In patients treated with HDR-IORT, a significantly greater number of major complications was observed compared with patients treated with IOERT (46\% and 26\%, respectively; $P=.017$ ). 
Table 3 Patient, tumor, and surgical characteristics in patients with locally recurrent rectal cancer*

\begin{tabular}{|c|c|c|c|c|}
\hline Characteristic & $\begin{array}{l}\text { Total, No. }(\%) \\
\quad(\mathrm{N}=158)\end{array}$ & $\begin{array}{l}\text { IOERT, No. }(\%) \\
\quad(\mathrm{n}=112)\end{array}$ & $\begin{array}{l}\text { HDR-IORT, No. }(\%) \\
(\mathrm{n}=46)\end{array}$ & $P$ value \\
\hline \multicolumn{5}{|l|}{ Gender } \\
\hline Female & $54(34)$ & $38(34)$ & $16(35)$ & \multirow[t]{2}{*}{.918} \\
\hline Male & $104(66)$ & $74(66)$ & $30(65)$ & \\
\hline \multicolumn{5}{|l|}{ Age at resection, $\mathrm{y}$} \\
\hline$<70$ & $122(77)$ & $88(79)$ & $34(74)$ & \multirow[t]{2}{*}{.526} \\
\hline$\geq 70$ & $36(23)$ & $24(21)$ & $12(26)$ & \\
\hline \multicolumn{5}{|c|}{ Clinical tumor stage, primary tumor } \\
\hline cT1-2 & $28(18)$ & $17(16)$ & $11(24)$ & \multirow[t]{2}{*}{.209} \\
\hline cT3-4 & $128(82)$ & $93(85)$ & $35(76)$ & \\
\hline \multicolumn{5}{|c|}{ Clinical nodal stage, primary tumor } \\
\hline $\mathrm{cNO}$ & $76(49)$ & $52(47)$ & $24(52)$ & \multirow[t]{3}{*}{.849} \\
\hline $\mathrm{cN} 1$ & $50(32)$ & $36(33)$ & $14(30)$ & \\
\hline $\mathrm{cN} 2$ & $30(19)$ & $22(20)$ & $8(17)$ & \\
\hline \multicolumn{5}{|l|}{ History of metastases } \\
\hline Yes & $21(14)$ & $13(12)$ & $8(17)$ & \multirow[t]{2}{*}{.400} \\
\hline No & $131(86)$ & $93(88)$ & $38(83)$ & \\
\hline \multicolumn{5}{|c|}{ Neoadjuvant treatment, primary tumor } \\
\hline None & $67(42)$ & $39(35)$ & $28(61)$ & \multirow[t]{3}{*}{.008} \\
\hline $5 \times 5$ Radiation therapy & $48(30)$ & $40(35)$ & $8(17)$ & \\
\hline (Chemo)radiation therapy & $43(27)$ & $33(30)$ & $10(22)$ & \\
\hline \multicolumn{5}{|c|}{ Surgical procedure, primary tumor } \\
\hline Local excision & $5(3)$ & $3(3)$ & $2(4)$ & \multirow[t]{4}{*}{.670} \\
\hline (Recto)sigmoid resection & $15(10)$ & $9(8)$ & $6(13)$ & \\
\hline LAR & $82(52)$ & $60(54)$ & $22(48)$ & \\
\hline APR & $56(35)$ & $40(36)$ & $16(35)$ & \\
\hline \multicolumn{5}{|l|}{ Synchronous metastases } \\
\hline Yes & $21(13)$ & $14(13)$ & $7(15)$ & \multirow[t]{2}{*}{.648} \\
\hline No & $137(87)$ & $98(88)$ & $39(85)$ & \\
\hline \multicolumn{5}{|c|}{ Neoadjuvant chemotherapy recurrence } \\
\hline Yes & $28(18)$ & $22(20)$ & $6(13)$ & \multirow[t]{2}{*}{.324} \\
\hline No & $130(82)$ & $90(80)$ & $40(87)$ & \\
\hline \multicolumn{5}{|c|}{ Neoadjuvant radiation therapy recurrence } \\
\hline $5 \times 5$ Radiation therapy & $4(3)$ & $1(1)$ & $3(7)$ & \multirow[t]{3}{*}{.001} \\
\hline (Chemo)radiation therapy & $56(35)$ & $32(29)$ & $24(52)$ & \\
\hline (Chemo)reirradiation & $98(62)$ & $79(71)$ & $19(41)$ & \\
\hline Interval radiation therapy $-s u$ & & & & \\
\hline$<8$ & $30(20)$ & $13(13)$ & $17(39)$ & .001 \\
\hline $8-12$ & $65(44)$ & $52(50)$ & $13(30)$ & \\
\hline$>12$ & $53(36)$ & $39(38)$ & $14(32)$ & \\
\hline Surgical procedure & & & & \\
\hline LAR & $18(11)$ & $11(10)$ & $7(15)$ & .112 \\
\hline APR & $15(10)$ & $7(6)$ & $8(17)$ & \\
\hline Multivisceral resection & $108(68)$ & $81(72)$ & $27(58)$ & \\
\hline Nonvisceral resection & $17(11)$ & $13(12)$ & $4(9)$ & \\
\hline Procedure time, $\mathrm{h}$ & & & & \\
\hline $0-3$ & $2(1)$ & $2(2)$ & $0(0)$ & $<.001$ \\
\hline $3-5$ & $28(19)$ & $27(26)$ & $1(2)$ & \\
\hline$>5$ & $120(80)$ & $76(72)$ & $44(98)$ & \\
\hline Adjuvant therapy & & & & \\
\hline None & $153(100)$ & $107(100)$ & $46(100)$ & - \\
\hline Complications & & & & \\
\hline Clavien-Dindo 0-II & $107(68)$ & $82(74)$ & $25(54)$ & .017 \\
\hline Clavien-Dindo III-V & $50(32)$ & $29(26)$ & $21(46)$ & \\
\hline
\end{tabular}

Abbreviations: APR = abdominoperineal resection; HDR-IORT = high-dose-rate intraoperative brachytherapy; IOERT = intraoperative electron beam radiation therapy; $\mathrm{LAR}=$ low anterior resection.

* Missing data were not included in group comparisons. Percentages may not sum to 100 owing to rounding. 


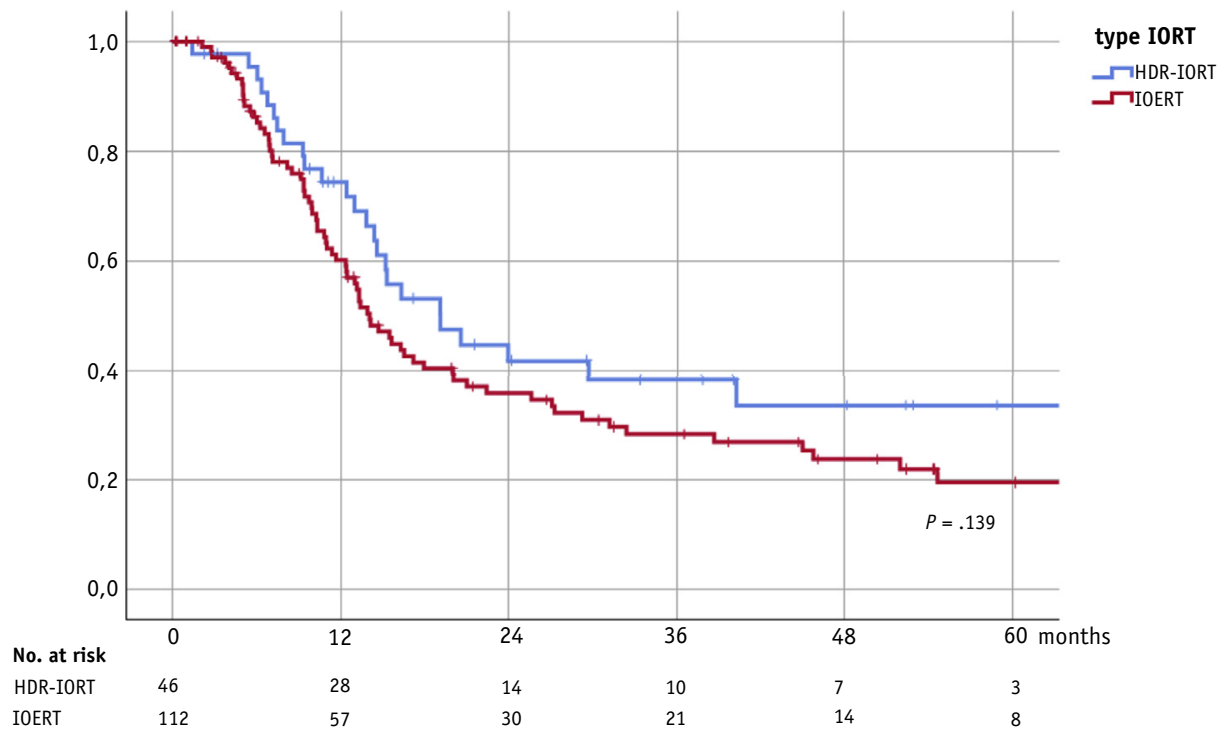

Fig. 2. Kaplan-Meier curve for local recurrence-free survival in patients with locally recurrent rectal cancer.

In patients who experienced a major complication, the most common were presacral abscess (26\%), leakage of the ureter or bladder reconstruction $(12 \%)$, abdominal wound dehiscence with evisceration (8\%), and intraabdominal abscess (6\%) (Table E2). In-hospital mortality was observed in 4 of 112 patients (4\%) in the IOERT group and in 1 of 46 patients $(2 \%)$ in the HDR-IORT group $(P>.999)$.

\section{Discussion}

This retrospective study of data from two large tertiary referral centers showed a favorable LRFS for patients treated with HDR-IORT compared with those treated with IOERT after an R1 resection for LARC or LRRC. This difference suggests a dose-dependent efficacy of IORT, as HDR-IORT delivers a higher surface dose compared with IOERT. Moreover, the fact that one modality was more effective than the other indicates that IORT has a measurable effect on LRFS in R1 patients; to our knowledge, this has not been shown previously in a large comparative study.

Several published studies have assessed the feasibility and efficacy of administering IORT in patients with LARC and/or LRRC. The majority of these studies have focused on the use of IOERT and, to a lesser extent, HDR-IORT. ${ }^{12}$ Only a few have reported on the use of both techniques, but to our knowledge, this is the first to compare the IOERT and HDR-IORT treatment modalities..$^{20,21}$

The difference in LRFS between HDR-IORT and IOERT observed in the current study may have been caused by differences in dose distributions between the two IORT modalities. HDR-IORT is delivered at a much more concentrated dose to the surface of the target area; the estimated dose at the target surface was $170 \%$ of the prescribed 10 Gy dose at a 10-mm depth. IOERT delivers the radiation dose more homogeneously throughout the tissue depth, but as a consequence, it delivers a surface dose equal to the prescribed dose. Adjusting the IOERT procedure by increasing the surface dose with the use of a bolus and adapting the dose at a $10-\mathrm{mm}$ depth to ensure it is equal to the HDR-IORT prescribed dose could result in a dose distribution that is more similar to that of HDR-IORT.

In addition, the size of the treated surface may also play a role in the observed difference in LRFS between both IORT modalities. Although we could not specify the irradiated area for HDR-IORT in this study, previous work has shown that the mean treated area is $73 \mathrm{~cm}^{2}$ (range, 25-170 $\mathrm{cm}^{2}$ ), which is 2 to 3 times larger than the area treated with IOERT. ${ }^{22}$ Furthermore, IOERT applicators are poorly suited to curved areas such as the presacral and posterolateral area, in contrast to the flexible applicators used in HDRIORT. However, we do not believe this played a role in the better dose delivery by HDR-IORT, as we corrected for the problems caused by the rigid applicators, such as minor airgaps and a limited diameter of the tube.

In the patients with LRRC, significant baseline differences between the two IORT modalities were observed regarding the neoadjuvant treatment and the time between EBRT and surgery. Previous work published by Holman et al showed that a waiting time shorter than 8 weeks, as was observed in the HDR-IORT group, resulted in better LRFS in patients with an R1 resection. ${ }^{23,24}$ This factor could also have played a role in the observed difference in LRFS between HDR-IORT and IOERT treatment groups in this study. However, in the multivariable analysis, we adjusted for these differences.

There was no observed difference in major postoperative complications between the two IORT modalities in patients with LARC. On the other hand, in patients with LRRC, HDR-IORT was associated with a significantly greater 
Table 4 Univariable and multivariable analysis for overall and local recurrence-free survival in patients with locally recurrent rectal cancer*

\begin{tabular}{|c|c|c|c|c|c|c|c|c|c|c|c|c|}
\hline \multirow[b]{2}{*}{ Variable } & \multicolumn{6}{|c|}{ Overall survival } & \multicolumn{6}{|c|}{ Local recurrence-free survival } \\
\hline & HR & $95 \% \mathrm{CI}$ & $\begin{array}{c}P \\
\text { value }\end{array}$ & HR & $95 \% \mathrm{CI}$ & $\begin{array}{c}P \\
\text { value }\end{array}$ & HR & $95 \% \mathrm{CI}$ & $\begin{array}{c}P \\
\text { value }\end{array}$ & HR & $95 \% \mathrm{CI}$ & $\begin{array}{c}P \\
\text { value }\end{array}$ \\
\hline \multicolumn{13}{|l|}{ Type of IORT } \\
\hline IOERT & 1.00 & $1[\operatorname{Ref}]$ & & 1.00 & $1[\operatorname{Ref}]$ & & 1.00 & $1[$ Ref $]$ & & 1.00 & $1[\operatorname{Ref}]$ & \\
\hline HDR-IOBT & 1.062 & $\begin{array}{l}0.737- \\
1.531\end{array}$ & .747 & 1.168 & $\begin{array}{l}0.792- \\
1.722\end{array}$ & .433 & 0.711 & $\begin{array}{l}0.451- \\
1.120\end{array}$ & .141 & 0.567 & $\begin{array}{l}0.349- \\
0.920\end{array}$ & .021 \\
\hline \multicolumn{13}{|l|}{ Age, y } \\
\hline$<70$ & 1.00 & $1[\operatorname{Ref}]$ & & 1.00 & $1[\operatorname{Ref}]$ & & 1.00 & $1[$ Ref $]$ & & & & \\
\hline$\geq 70$ & 1.753 & $\begin{array}{l}1.191- \\
2.581\end{array}$ & .004 & 1.942 & $\begin{array}{l}1.301- \\
2.900\end{array}$ & .001 & 1.476 & $\begin{array}{l}0.916- \\
2.379\end{array}$ & .110 & & & \\
\hline \multicolumn{13}{|l|}{ Sex } \\
\hline Male & 1.00 & $1[\operatorname{Ref}]$ & & & & & 1.00 & $1[$ Ref $]$ & & & & \\
\hline Female & 1.013 & $\begin{array}{l}0.715- \\
1.435\end{array}$ & .942 & & & & 0.787 & $\begin{array}{l}0.513- \\
1.207\end{array}$ & .272 & & & \\
\hline \multicolumn{13}{|l|}{$\begin{array}{l}\text { Pathologic tumor stage, } \\
\text { primary tumor }\end{array}$} \\
\hline $\mathrm{T} 3$ & 1.00 & $1[\operatorname{Ref}]$ & & & & & 1.00 & $1[\operatorname{Ref}]$ & & 1.00 & $1[\operatorname{Ref}]$ & \\
\hline $\mathrm{T} 4$ & 0.952 & $\begin{array}{l}0.615- \\
1.472\end{array}$ & .824 & & & & 0.586 & $\begin{array}{l}0.366- \\
0.937\end{array}$ & .026 & 0.564 & $\begin{array}{l}0.339- \\
0.936\end{array}$ & .027 \\
\hline \multicolumn{13}{|l|}{$\begin{array}{l}\text { Pathologic lymph node stage, } \\
\text { primary tumor }\end{array}$} \\
\hline No & 1.00 & $1[\operatorname{Ref}]$ & & 1.00 & $1[\operatorname{Ref}]$ & & 1.00 & $1[$ Ref $]$ & & 1.00 & $1[\operatorname{Ref}]$ & \\
\hline N1 & 1.335 & $\begin{array}{l}0.906- \\
1.967\end{array}$ & .144 & 1.236 & $\begin{array}{l}0.820- \\
1.864\end{array}$ & .311 & 0.908 & $\begin{array}{l}0.567- \\
1.456\end{array}$ & .690 & 0.986 & $\begin{array}{l}0.602- \\
1.616\end{array}$ & .955 \\
\hline $\mathrm{N} 2$ & 1.820 & $\begin{array}{l}1.165- \\
2.842\end{array}$ & .008 & 1.879 & $\begin{array}{l}1.199- \\
3.001\end{array}$ & .006 & 1.914 & $\begin{array}{l}1.135- \\
3.229\end{array}$ & .015 & 2.099 & $\begin{array}{l}1.228- \\
3.588\end{array}$ & .007 \\
\hline \multicolumn{13}{|l|}{ History of metastases } \\
\hline No & 1.00 & $1[\operatorname{Ref}]$ & & & & & 1.00 & $1[$ Ref $]$ & & & & \\
\hline Yes & 1.542 & $\begin{array}{l}0.954- \\
2.492\end{array}$ & .077 & & & & 1.070 & $\begin{array}{l}0.569- \\
2.012\end{array}$ & .834 & & & \\
\hline \multicolumn{13}{|l|}{$\begin{array}{l}\text { Neoadjuvant therapy, primary } \\
\text { tumor }\end{array}$} \\
\hline None & 1.00 & $1[\operatorname{Ref}]$ & & & & & 1.00 & $1[$ Ref $]$ & & & & \\
\hline 5x5 Radiation therapy & 1.346 & $\begin{array}{l}0.904- \\
2.003\end{array}$ & .143 & & & & 1.666 & $\begin{array}{l}1.035- \\
2.682\end{array}$ & .036 & & & \\
\hline (Chemo)radiation therapy & 1.594 & $\begin{array}{l}1.046- \\
2.428\end{array}$ & .030 & & & & 1.932 & $\begin{array}{l}1.183- \\
3.153\end{array}$ & .008 & & & \\
\hline \multicolumn{13}{|l|}{ Surgery, primary tumor } \\
\hline APR & 1.00 & $1[\operatorname{Ref}]$ & & & & & 1.00 & $1[$ Ref $]$ & & & & \\
\hline Local excision & 1.219 & $\begin{array}{l}0.446- \\
3.332\end{array}$ & .699 & & & & 0.886 & $\begin{array}{l}0.272- \\
2.890\end{array}$ & .841 & & & \\
\hline Rectosigmoid/LAR & 1.279 & $\begin{array}{l}0.460- \\
3.559\end{array}$ & .637 & & & & 0.886 & $\begin{array}{l}0.584- \\
1.346\end{array}$ & .572 & & & \\
\hline \multicolumn{13}{|l|}{ Synchronous metastases } \\
\hline No & 1.00 & $1[\operatorname{Ref}]$ & & & & & 1.00 & $1[$ Ref $]$ & & & & \\
\hline Yes & 1.220 & $\begin{array}{l}0.751- \\
1.981\end{array}$ & .423 & & & & 0.971 & $\begin{array}{l}0.530- \\
1.778\end{array}$ & .924 & & & \\
\hline \multicolumn{13}{|l|}{ Neoadjuvant chemotherapy } \\
\hline No & 1.00 & $1[\operatorname{Ref}]$ & & & & & 1.00 & $1[$ Ref $]$ & & & & \\
\hline Yes & 1.191 & $\begin{array}{l}0.765- \\
1.854\end{array}$ & .438 & & & & 1.447 & $\begin{array}{l}0.891- \\
2.350\end{array}$ & .135 & & & \\
\hline \multicolumn{13}{|l|}{ Neoadjuvant radiation therapy } \\
\hline 5x5 Radiotherapy & 1.00 & $1[\operatorname{Ref}]$ & & & & & 1.00 & $1[$ Ref $]$ & & & & \\
\hline (Chemo)radiotherapy & 1.139 & $\begin{array}{l}0.354- \\
3.666\end{array}$ & .828 & & & & 0.539 & $\begin{array}{l}0.164- \\
1.769\end{array}$ & .308 & & & \\
\hline
\end{tabular}


Table 4 (continued)

\begin{tabular}{|c|c|c|c|c|c|c|c|c|c|c|c|c|}
\hline \multirow[b]{2}{*}{ Variable } & \multicolumn{6}{|c|}{ Overall survival } & \multicolumn{6}{|c|}{ Local recurrence-free survival } \\
\hline & HR & $95 \% \mathrm{CI}$ & $\begin{array}{c}P \\
\text { value }\end{array}$ & HR & $95 \% \mathrm{CI}$ & $\begin{array}{c}P \\
\text { value }\end{array}$ & HR & $95 \% \mathrm{CI}$ & $\begin{array}{c}P \\
\text { value }\end{array}$ & HR & $95 \% \mathrm{CI}$ & $\begin{array}{c}P \\
\text { value }\end{array}$ \\
\hline (Chemo)reirradiadtion & 1.512 & $\begin{array}{l}0.475- \\
4.815\end{array}$ & .484 & & & & 0.922 & $\begin{array}{l}0.288- \\
2.950\end{array}$ & .891 & & & \\
\hline \multicolumn{13}{|c|}{$\begin{array}{l}\text { Time between RT and surgery, } \\
\text { wk }\end{array}$} \\
\hline$<8$ & 1.00 & $1[\operatorname{Ref}]$ & & & & & 1.00 & $1[\operatorname{Ref}]$ & & & & \\
\hline $8-12$ & 1.120 & $\begin{array}{l}0.705- \\
1.780\end{array}$ & .631 & & & & 1.556 & $\begin{array}{l}0.865- \\
2.798\end{array}$ & .140 & & & \\
\hline$>12$ & 1.399 & $\begin{array}{l}0.860- \\
2.276\end{array}$ & .176 & & & & 1.890 & $\begin{array}{l}1.029- \\
3.478\end{array}$ & .040 & & & \\
\hline \multicolumn{13}{|l|}{ Type of surgery } \\
\hline LAR & 1.00 & $1[\operatorname{Ref}]$ & & & & & 1.00 & $1[\operatorname{Ref}]$ & & & & \\
\hline APR & 0.807 & $\begin{array}{l}0.380- \\
1.711\end{array}$ & .575 & & & & 1.143 & $\begin{array}{l}0.476- \\
2.748\end{array}$ & .765 & & & \\
\hline Multivisceral resection & 0.923 & $\begin{array}{l}0.556- \\
1.532\end{array}$ & .755 & & & & 1.226 & $\begin{array}{l}0.631- \\
2.381\end{array}$ & .548 & & & \\
\hline Nonvisceral resection & 1.000 & $\begin{array}{l}0.509- \\
1.963\end{array}$ & 1.000 & & & & 0.875 & $\begin{array}{l}0.355- \\
2.155\end{array}$ & .771 & & & \\
\hline \multicolumn{13}{|l|}{ Complications } \\
\hline Clavien-Dindo 0-II & 1.00 & $1[\mathrm{Ref}]$ & & & & & 1.00 & $1[\operatorname{Ref}]$ & & & & \\
\hline Clavien-Dindo III-V & 1.399 & $\begin{array}{l}0.978- \\
2.001\end{array}$ & .066 & & & & 0.738 & $\begin{array}{l}0.466- \\
1.170\end{array}$ & .197 & & & \\
\hline
\end{tabular}

number of major postoperative complications compared with IOERT. Hypothetically, HDR-IORT induces more tissue damage and necrosis, owing to a higher surface dosage and a larger irradiated surface area compared with IOERT, which may increase the likelihood of postoperative complications. This hypothesis could not be explored further within this study, owing to the low frequency of each distinct complication event.

Another significant difference observed between the two groups was the duration of the procedure. As mentioned, HDR-IORT is a more time-consuming procedure to perform, because it requires individual treatment planning as well as a longer application time. Thus, the difference in the duration of the procedure is mainly the result of the IORT modality and not the extent of the surgery itself.

Despite the aforementioned difference in neoadjuvant treatment (which is a result of referral patterns rather than treatment strategies) and the time between EBRT and IORT in patients with LRRC, there were no baseline differences between the IOERT and HDR-IORT groups. Furthermore, both hospitals followed the same national guidelines regarding diagnostics and neoadjuvant treatment planning, and the preoperative, perioperative, and postoperative protocols, as well as the follow-up schedule, were similar between both hospitals. Moreover, most surgeons responsible for performing the procedures involved in this study worked at both hospitals and agreed that the case mix in both hospitals was similar. Hence, we feel that this study provides a valid comparison of the two IORT modalities.

IORT was not delivered to all patients with an R1 resection in our institutions. In patients with LARC, treatment with IORT was not delivered in cases of palliative resections or as a consequence of an incorrect clinical judgment of the resection margin status, false-negatives based on analysis of frozen sections, or technical problems encountered during surgery (eg, hemodynamic instability in the patient). In patients with LRRC, IORT was mainly omitted because of a high cumulative dose owing to prior (intraoperative) irradiation that did not allow an additional IORT boost. In addition, palliative resections and surgical technical problems (eg, hemodynamic instability in patients) were reasons to omit IORT.

With the evolving neoadjuvant treatment strategies, it remains important to bear in mind the possibility of delivering IORT. A neoadjuvant treatment strategy in which neoadjuvant radiation therapy is followed by consolidation chemotherapy as proposed in the Rectal Cancer And Preoperative Induction Therapy Followed by Dedicated Operation (RAPIDO) trial results in a longer interval between the radiation therapy and IORT compared with the so-called "total neoadjuvant treatment" strategies, in which neoadjuvant radiation therapy is preceded by induction chemotherapy; thus, a shorter interval between radiation therapy and IORT exists. ${ }^{25,26}$ Although a longer waiting 
time increases the chance of an $\mathrm{R} 0$ resection, a shorter interval seems to benefit the effect of IORT in case of an R1 resection (Table 2). ${ }^{23,24}$

Owing to the retrospective nature of this study, there were some apparent shortcomings. However, as a result of the prospective maintenance of the database, very few data were missing: specifically, $2 \%$ and $1.6 \%$ of the values reported in Tables 2 and 4, respectively. Nonetheless, we could not specifically report on long-term complications associated with IORT. In particular, it would be of interest to compare complications such as plexopathy and peripheral neuropathy, which are known to be dose-dependent late toxicities associated with pelvic IORT, between the two modalities. ${ }^{27}$ Furthermore, the patterns of (re)recurrence (infield or outfield) were missing in $37 \%$ of patients with LARC and $24 \%$ of patients with LRRC, so no related conclusions could be drawn.

In conclusion, in this retrospective cohort study from two large tertiary referral centers, a significant difference in the efficacy of IORT modalities was observed in patients with an R1 resection for LARC or LRRC, in favor of HDRIORT. Therefore, the CZE is currently in the process of adapting the IOERT procedure to improve outcomes, while limiting the toxicity, in patients with an $\mathrm{R} 1$ resection for LARC or LRRC.

\section{References}

1. Sauer R, Liersch T, Merkel S, et al. Preoperative versus postoperative chemoradiotherapy for locally advanced rectal cancer: Results of the German CAO/ARO/AIO-94 randomized phase III trial after a median follow-up of 11 years. J Clin Oncol 2012;30:1926-1933.

2. Gérard JP, Conroy T, Bonnetain F, et al. Preoperative radiotherapy with or without concurrent fluorouracil and leucovorin in T3-4 rectal cancers: Results of FFCD 9203. J Clin Oncol 2006;24:4620-4625.

3. PelvEx Collaborative. Surgical and survival outcomes following pelvic exenteration for locally advanced primary rectal cancer. Ann Surg 2019;269:315-321.

4. Platt E, Dovell G, Smolarek S. Systematic review of outcomes following pelvic exenteration for the treatment of primary and recurrent locally advanced rectal cancer. Tech Coloproctol 2018;22:835845.

5. Nielsen M, Rasmussen P, Pedersen B, Hagemann-Madsen R, Lindegaard J, Laurberg S. Early and late outcomes of surgery for locally recurrent rectal cancer: A prospective 10-year study in the total mesorectal excision era. Ann Surg Oncol 2015;22:2677-2684.

6. Marijnen CAM, Nagtegaal ID, Kapiteijn E, et al. Radiotherapy does not compensate for positive resection margins in rectal cancer patients: Report of a multicenter randomized trial. Int J Radiat Oncol Biol Phys 2003;55:1311-1320.

7. Gunderson LL, Calvo FA, Willett CG, Harrison LB. Rationale and historical perspective of intraoperative irradiation. Gunderson LL, Willett CG, Calvo FA, Harrison LB, editors. Intraoperative Irradiation: Techniques and Results. 2nd ed. Totowa, NJ: Humana Press; 2011. p. 3-26.

8. Okunieff P, Sundararaman S, Metcalfe S, Chen Y. Biology of large dose per fraction irradiation. Gunderson LL, Willett CG, Calvo FA, Harrison LB, editors. Intraoperative Irradiation: Techniques and Results. 2nd ed. Totowa, NJ: Humana Press; 2011. p. 27-47.

9. Allee P, Tepper J, Gunderson L, Munzenrider J. Postoperative radiation therapy for incompletely resected colorectal carcinoma. Int J Radiat Oncol Biol Phys 1989;17:1171-1176.
10. Alberda WJ, Verhoef C, Nuyttens JJ, et al. Intraoperative radiation therapy reduces local recurrence rates in patients with microscopically involved circumferential resection margins after resection of locally advanced rectal cancer. Int J Radiat Oncol Biol Phys 2014;88:10321040.

11. Ferenschild FTJ, Vermaas M, Nuyttens JJME, et al. Value of intraoperative radiotherapy in locally advanced rectal cancer. Dis Colon Rectum 2006;49:1257-1265.

12. Mirnezami R, Chang GJ, Das $P$, et al. Intraoperative radiotherapy in colorectal cancer: Systematic review and meta-analysis of techniques, long-term outcomes, and complications. Surg Oncol 2013;22:22-35.

13. Calvo FA, Sole CV, Rutten HJT, et al. ESTRO/ACROP IORT recommendations for intraoperative radiation therapy in locally recurrent rectal cancer. Clin Transl Radiat Oncol 2020;24:41-48.

14. Nag S, Willet CG, Gunderson LL, Harrison LB, Calvo FA, Biggs P. IORT with electron-beam, high-dose-rate brachytherapy or lowKV/electronic brachytherapy: Methodological comparisons. Gunderson LL, Willett CG, Calvo FA, Harrison LB, editors. Intraoperative Irradiation: Techniques and Results. 2nd ed. Totowa, NJ: Humana Press; 2011. p. 99-115.

15. Nagtegaal ID, Marijnen CAM, Kranenbarg EK, Van De Velde CJH, Van Krieken JHJM. Circumferential margin involvement is still an important predictor of local recurrence in rectal carcinoma: Not one millimeter but two millimeters is the limit. Am J Surg Pathol 2002;26: 350-357.

16. Bhangu A, Ali SM, Darzi A, Brown G, Tekkis PP. Meta-analysis of survival based on resection margin status following surgery for recurrent rectal cancer. Color Dis 2012;14:1457-1466.

17. Mannaerts GHH, Martijn H, Crommelin MA, et al. Feasibility and first results of multimodality treatment, combining EBRT, extensive surgery, and IOERT in locally advanced primary rectal cancer. Int $J$ Radiat Oncol Biol Phys 2000;47:425-433.

18. Nuyttens JJ, Kolkman-Deurloo IKK, Vermaas M, et al. High-dose-rate intraoperative radiotherapy for close or positive margins in patients with locally advanced or recurrent rectal cancer. Int J Radiat Oncol Biol Phys 2004;58:106-112.

19. Dindo D, Demartines N, Clavien P-A. Classification of surgical complications: A new proposal with evaluation in a cohort of 6336 patients and results of a survey. Ann Surg 2004;240:205-213.

20. Vermaas M, Nuyttens JJME, Ferenschild FTJ, Verhoef C, Eggermont AMM, de Wilt JHW. Reirradiation, surgery and IORT for recurrent rectal cancer in previously irradiated patients. Radiother Oncol 2008;87:357-360.

21. Martínez-Monge R, Nag S, Martin EW. Three different intraoperative radiation modalities (electron beam, high-dose-rate brachytherapy, and iodine-125 brachytherapy) in the adjuvant treatment of patients with recurrent colorectal adenocarcinoma. Cancer 1999;86:236-247.

22. Kolkman-Deurloo IKK, Nuyttens JJ, Hanssens PEJ, Levendag PC. Intraoperative HDR brachytherapy for rectal cancer using a flexible intraoperative template: Standard plans versus individual planning. Radiother Oncol 2004;70:75-79.

23. Holman FA, Bosman SJ, Haddock MG, et al. Results of a pooled analysis of IOERT containing multimodality treatment for locally recurrent rectal cancer: Results of 565 patients of two major treatment centres. Eur J Surg Oncol 2017;43:107-117.

24. Holman FA, Haddock MG, Gunderson LL, et al. Results of intraoperative electron beam radiotherapy containing multimodality treatment for locally unresectable T4 rectal cancer: A pooled analysis of the Mayo Clinic Rochester and Catharina Hospital Eindhoven. J Gastrointest Oncol 2016;7:903-916.

25. Nilsson PJ, van Etten B, Hospers GAP, et al. Short-course radiotherapy followed by neo-adjuvant chemotherapy in locally advanced rectal cancer-The RAPIDO trial. BMC Cancer 2013;279.

26. Ludmir EB, Palta M, Willett CG, Czito BG. Total neoadjuvant therapy for rectal cancer: An emerging option. Cancer 2017;123:1497-1506.

27. Pilar A, Gupta M, Laskar SG, Laskar S. Intraoperative radiotherapy: Review of techniques and results. Ecancermedicalscience 2017;11: 750. 